\title{
Effect of mulching and fertilization on the quality of strawberries
}

\author{
Ulvi Moor, Kadri Karp and Priit Põldma \\ Institute of Horticulture, Estonian Agricultural University, Kreutzwaldi 64, Tartu 51014, Estonia, \\ e-mail:ulvi26@hot.ee
}

\begin{abstract}
A large part of the research carried out with strawberries (Fragaria $\times$ ananassa) has been with the aim of gaining higher yields. At the same time postharvest losses are remarkable. Therefore the need for research with the aim of increasing quality is rising. The aim of the present research was to study the influence of mulch (plastic and straw), fertilization and the age of plants (two, three and four years) on the quality of strawberry fruits. Experiments were carried out with cultivar Bounty during 2000-2002 at the Estonian Agricultural University. Results showed that fertilization had a positive effect on the yield of first grade fruits with both mulches. With plastic mulch, fertilization had a positive influence on vitamin $\mathrm{C}$ content. With straw mulch, fertilization decreased fruit damage. None of the experimental factors had an impact on the content of soluble solids. We concluded that injecting fertilizer solution into the soil under plastic mulch is an effective and inexpensive way to avoid a decrease in fruit size in the third year of production. Vitamin $\mathrm{C}$ content was negatively influenced by plant age, and in the three-year-old plantation, smaller fruits contained more vitamin $\mathrm{C}$ than larger fruits.
\end{abstract}

Key words: Fragaria ananassa, strawberries, mulching, fertilizers, crop quality, vitamin C, fruit cracking

\section{Introduction}

A large part of the scientific research carried out with strawberries (Fragaria $\times$ ananassa) has been with the aim of gaining higher yields. At the same time, almost $40 \%$ of the strawberry fruits can be lost after picking, mostly to decay
(Ceponis et al. 1987). Therefore, at the end of the last century and at the present time several leading scientists have pointed out the need to change the research trend in horticulture from increasing productivity to increasing quality.

Quality as a term is often used, but rarely defined in postharvest studies. Quality attributes are very different when viewed from the perspec- 
tive of the product or from the perspective of the consumer (Nwankwo 1995). Most postharvest research assumes a product-oriented quality (Shewfelt 1999). The results of such research lack external validity or the extent to which the test results can be generalized to market behaviour (Van Trijp and Schifferstein 1995). Consumer-oriented studies focus more on how to measure human perception and behaviour and are also focused on predicting product performance in the marketplace. A consumer-oriented approach also has its limitations, since consumer preferences vary substantially, depending on many factors. A significant quality paradox is that management decisions to extend shelf life, made within a distribution chain, are all aimed at improving appearance, frequently at the expense of flavour (Prussia and Shewfelt 1993).

Several experiments have been carried out in recent years in Estonia to study the effect of growing technologies and plant age on strawberry yield. Results from these studies have shown that, during the first two production years, strawberry yields are high at the expense of reserve fertilizers (Lille et al. 2003). Therefore, high investment in drip-irrigation with the aim of applying fertilizer solution is not necessary. The yield of first-grade fruits decreases significantly in the third and fourth years of production, unless fertilizer is supplied. The decrease can be 20 or $66 \%$ respectively, compared to the second year of production (Karp and Starast 2002, Karp et al. 2002). Therefore an economical system for fertilizing plantations covered with plastic mulch, but without using drip-irrigation, is needed.

The aim of the present research was to find out whether it is possible to avoid a considerable decrease in fruit size by injecting fertilizers under the plastic mulch in a four-year-old plantation, and to study the influence of different mulches, fertilization, and plantation age on several quality characteristics of strawberry fruits.

\section{Material and methods}

\section{Experimental area and plant material}

The production field of the company Vasula Aed, which is situated in Tartu County, South Estonia, was used for the experiment. The soil type in the experimental area is podzoluvisols and average humus cover is $30 \mathrm{~cm}$ thick. Reserve fertilizers were applied according to the soil analyses before planting. Plants for the experiment were obtained from the open field nursery of the same company. The plantation was established as a field experiment using slightly raised beds (10 cm from ground) in a complete block design. Plants were planted in single rows and beds were covered with plastic or straw mulch as required for the experiment. Black polyethylene with a thickness of $0.04 \mathrm{~mm}$ and a width of $1 \mathrm{~m}$ was used as plastic mulch. In straw mulch variants, a $5-8 \mathrm{~cm}$ thick layer of wheat straw was applied on top of the soil. Spacing between the rows was $120 \mathrm{~cm}$ in the case of plastic mulch and $90 \mathrm{~cm}$ in the case of straw mulch; plant to plant spacing within the row was $33 \mathrm{~cm}$. No irrigation system was used in the experimental area. Strawberry cultivar Bounty was used in all experiments.

For the first experiment, the plantation was established in spring 1999. The following experimental variants were used in 2002:

1. Plastic mulch, without fertilizers.

2. Plastic mulch plus fertilizers. In this variant, fertilizer Kemfos (10:22.7:14) was used: $0.2 \%$ solution was injected under the plastic mulch into the soil next to every single plant just before flowering and at the beginning of flowering at a rate of 1 litre per plant. Thus, expressed as nutrients, this plantation received: $5 \mathrm{~kg} \mathrm{~N} \mathrm{ha}{ }^{-1}, 11.3 \mathrm{~kg} \mathrm{P} \mathrm{ha}^{-1}$ and $7 \mathrm{~kg} \mathrm{~K}$ $\mathrm{ha}^{-1}$. Additionally, at anthesis and at the beginning of maturation of fruits, the solution of complex fertilizer Kemira Ferticare 14:11:25 was injected at the same dose. Thus, expressed as nutrients, this plantation received: $7 \mathrm{~kg} \mathrm{~N} \mathrm{ha}{ }^{-1}, 5.5 \mathrm{~kg} \mathrm{P} \mathrm{ha}^{-1}$ and $12.5 \mathrm{~kg}$ 
$\mathrm{K} \mathrm{ha}^{-1}$. In total, the plantation received: 24 $\mathrm{kg} \mathrm{N} \mathrm{ha-1}, 33 \mathrm{~kg} \mathrm{P} \mathrm{ha}^{-1}$ and $39 \mathrm{~kg} \mathrm{~K} \mathrm{ha}^{-1}$. For the injection of fertilizers under the plastic mulch, special equipment consisting of an 800-litre tank with hoses and tubes attached to a tractor was used. Two persons walking behind the tractor applied the fertilizer solution (Fig. 1).

3. Straw mulch without fertilizers.

4. Straw mulch plus fertilizers. In this variant, the fertilizers were the same as in Variant 2, but the solution was applied from above onto the plant rows.

For the second experiment, strawberry plantations were established in spring 1998, 1999 and 2000. Reserve fertilizers were applied according to the soil analyses before planting. Experimental fields were covered with straw mulch as described earlier. Variants used in the second experiment were the following:

1. Plantation age -2 years (first yield).

2. Plantation age -3 years (second yield).

3. Plantation age -4 years (third yield).

All plots in this experiment were fertilized once a year in early spring with $250 \mathrm{~kg} \mathrm{ha}^{-1}$ of granulated strawberry fertilizer 8:2.6:14.1. Thus, expressed as nutrients, the above-mentioned three variants each received: $20 \mathrm{~kg} \mathrm{~N}^{-1}, 6.5$ $\mathrm{kg} \mathrm{P} \mathrm{ha}{ }^{-1}$ and $35.2 \mathrm{~kg} \mathrm{~K} \mathrm{ha}^{-1}$. Also, in all variants with straw mulch, defoliation was carried out every year by first cutting the leaves and then burning the straw together with the leaves in situ right after all fruits had been harvested. Soil between the rows was cultivated several times in autumn.

\section{Weather conditions}

In summer 2000 the temperature in May, June and July was close to the average of many years. The amount of precipitation also remained at the normal level for Estonia, only the total precipitation in July was higher.

Summer 2001 could be described as rainy: the amount of precipitation exceeded the average of many years in all three months. Tempera-

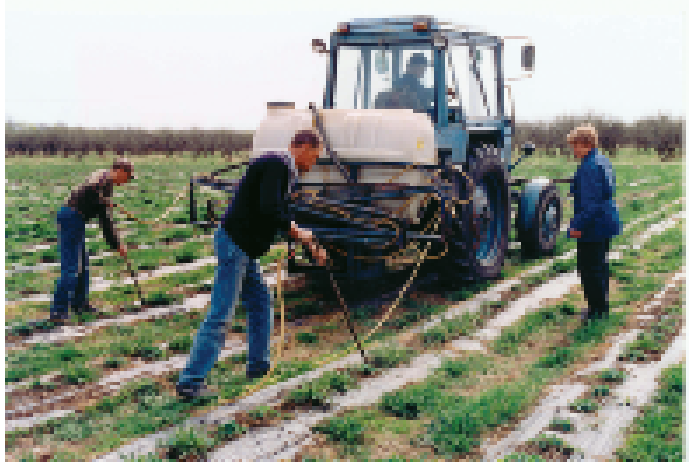

Fig. 1. Equipment used to inject fertilizer solution under the plastic mulch. (Photo: Kadri Karp)

ture remained at the average level until July, which was warmer than average.

Summer 2002 was warmer and with less precipitation than the average of many years in Estonia (Fig. 2). The photosynthetically active radiation (PAR) was also higher than average. The average temperature in May 2002 was $13.1^{\circ} \mathrm{C}$, in June $15.6^{\circ} \mathrm{C}$ and in July $19.0^{\circ} \mathrm{C}$, while the averages for $1966-1998$ for the same months were $11^{\circ} \mathrm{C}, 15^{\circ} \mathrm{C}$ and $17^{\circ} \mathrm{C}$, respectively. At the same time the first part of the summer was very dry. In May 2002, there was only $15 \mathrm{~mm}$ of rainfall, while the average of many years was $35 \mathrm{~mm}$. In June the amount of precipitation was $80 \mathrm{~mm}$, which exceeded the average $(66 \mathrm{~mm})$, but most of it came after 20 June. In July the amount of precipitation was $45 \mathrm{~mm}$, which was below the average $(72 \mathrm{~mm})$. PAR values were especially exceptional in May: PAR in May 2002 was 320 $\mathrm{MJm}^{-2}$, while the average for 1955-2000 was 242 $\mathrm{MJm}^{-2}$. In June the same figures were 268 and $266 \mathrm{MJm}^{-2}$ respectively, and in July 277 and 255 $\mathrm{MJm}^{-2}$. Thus we may say that PAR was somewhat higher than average also in July.

\section{Measurements and analyses}

The influence of plant age and mulching on the percentage of first quality fruits was studied dur- 


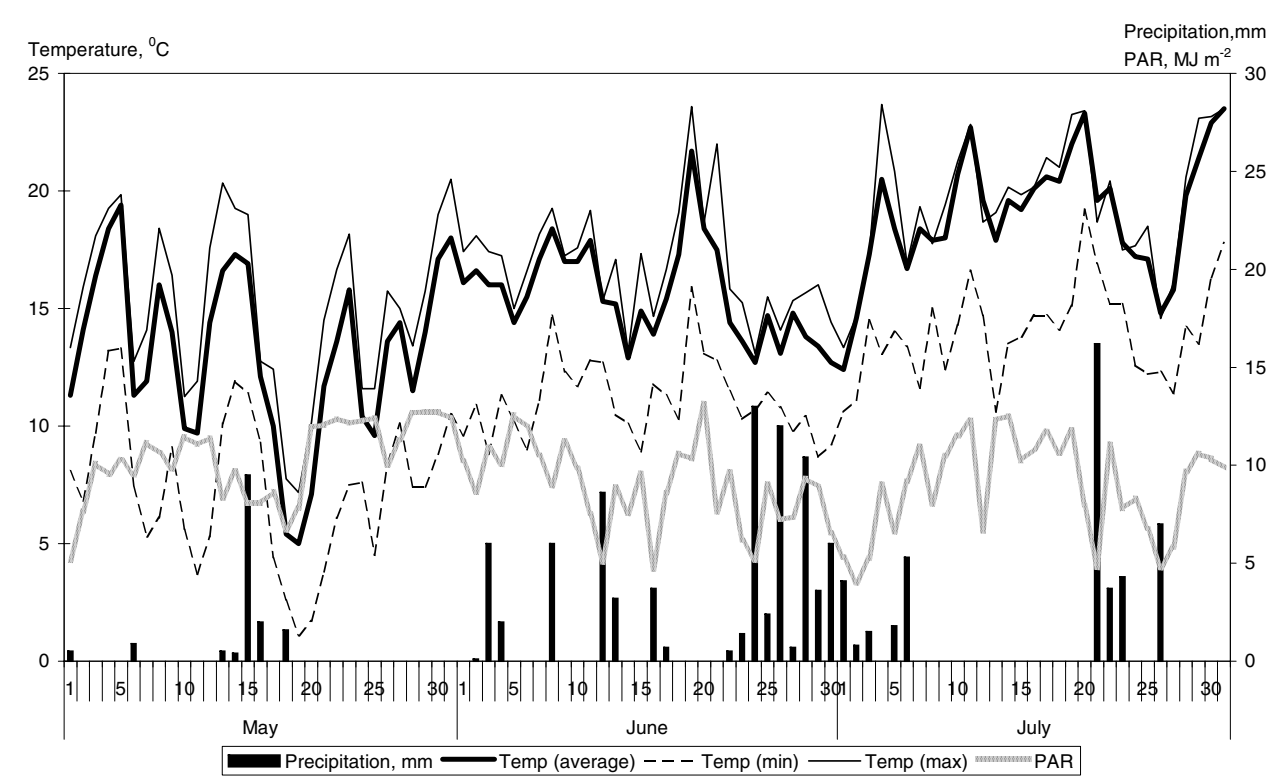

Fig. 2. Weather conditions in summer 2002: temperatures (average, minimum and maximum), ${ }^{\circ} \mathrm{C}$; precipitation, $\mathrm{mm}$ and photosynthetically active radiation (PAR), $\mathrm{MJm}^{-2}$.

ing three years (2000-2002). The total yield from 25 plants, in three replications, was harvested from each of the variants (plants grown with black plastic mulch, with straw mulch, and of different ages). Fruits were divided into three categories: first grade, second grade (fruits more than $2 \mathrm{~cm}$ and less than $2 \mathrm{~cm}$ in diameter, respectively) and spoiled fruits. Average yield of first grade fruits was calculated per plant.

Influence of the plantation age, fertilizers and mulching on the content of vitamin $\mathrm{C}$, soluble solids, and fruit cracking was studied in summer 2002. The fruiting period in 2002 started on 15 June, in both straw and plastic mulch variants, and was finished by 8 July in variants covered with plastic mulch and by 12 July in variants covered with straw mulch. Strawberry fruits were harvested seven times during the fruiting period.

Analysis of vitamin $\mathrm{C}$ was carried out at the Department of Chemistry, and all other measurements, at the Institute of Horticulture of the Estonian Agricultural University. On 17 June, 20 randomly chosen fruits, in three replications, were picked from each variant from the east side of the rows from positions where fruits were not covered with leaves. First grade fruits, with a diameter more than $2 \mathrm{~cm}$, were placed into cardboard boxes and were cooled down in a refrigerator at a temperature of $+5^{\circ} \mathrm{C}$ for $24 \mathrm{~h}$. The next day all fruits were individually weighed, and the content of soluble solids of each individual fruit was measured refractometrically. On 28 June, 10 fruits in three replications where picked from each variant and the vitamin $C$ content was measured using a modification of Tillman's method. On the same day, five strawberry plants were chosen at random from each variant, in three replications, and all ripe fruits were picked from those plants in order to study the fruit damage (cracks which started under the calyx and continued towards the tip of the fruit) that was noticed in most of the fruits after heavy rains in the latter third of June. Strawberry fruits were cooled down in a refrigerator for $24 \mathrm{~h}$. The next day, undamaged fruits were separated from dam- 
Moor, U. et al. Effect of mulching and fertilization on the quality of strawberries

aged ones and the percentage of cracked fruits was counted for each variant.

\section{Statistical methods}

To study the influence of mulch and fertilizers, data was analysed by two-way analysis of variance; for the influence of plant age, one-way analysis of variance was used; and to study correlation between different characteristics, regression analysis was used. The main effect means are presented in figures. Mean values to be compared are followed by the same letter if they are not significantly different at $\mathrm{P}=0.05$.

\section{Results and discussion}

\section{Strawberry yield and quality}

As earlier experiments in Estonia with strawberry cultivar Jonsok have shown, the influence of plant age on the increase in the number of small fruits is already obvious in the second yield for strawberries grown on plastic mulch (Karp et al. 2002). Results from the present research showed that with cultivar Bounty the yield of the first grade fruits does not decrease in the second yield, but decreases dramatically in the third yield (Fig. 3). In the present experiment, the number of first grade fruits declined significantly for both mulches: on average, only $59 \mathrm{~g}$ of first grade fruits per plant were obtained in the third yield, compared to $241 \mathrm{~g}$ per plant in the second yield. Even though the average effect of mulch was not significant, the decrease in first grade fruits on plastic mulch was somewhat larger than that on straw mulch: only $22 \mathrm{~g}$ of first quality fruits per plant were picked in the third production year compared to $238 \mathrm{~g}$ in the second production year. Since the covering of plantations with plastic mulch is an additional investment for the grower, such a yield loss in the third production year already is unacceptable and requires remediation.

Total yield of strawberry 'Bounty' fruits in a four-year-old plantation varied between $46 \mathrm{~g}$ per plant and 391 g per plant (Fig. 4). Total yield was

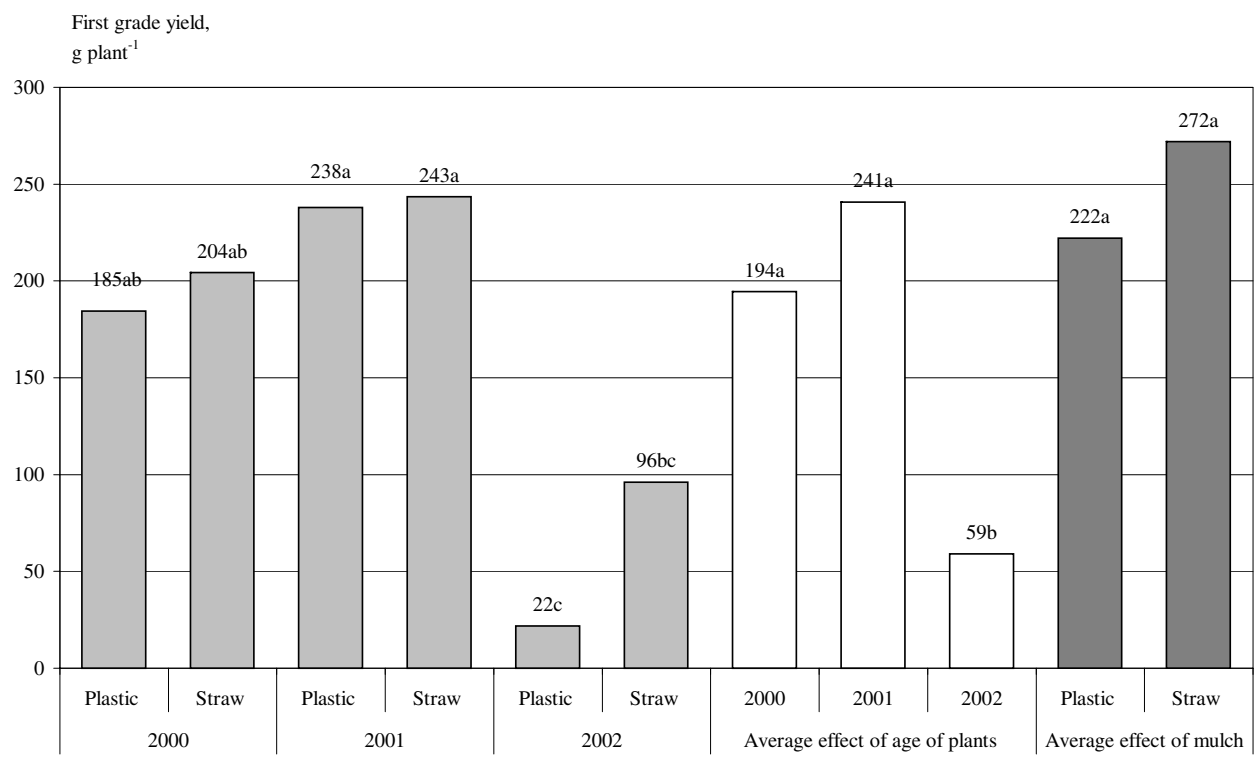

Fig. 3. The yield of first grade fruits, g per plant, grown with different mulches during 2000-2002. 
Vol. 13 (2004): 256-267.

lowest in the plastic mulch variant without fertilization and highest in the straw mulch variant without fertilization. In the present experiment, average effect of fertilization on total yield was insignificant, but mulch had a significant influence. Using straw mulch increased total yield by $73 \%$. At the same time, we have to bear in mind that total yield also contains second grade and spoiled fruits. For example, in the variant with highest total yield, $31 \%$ of fruits were spoiled, $44 \%$ were second grade fruits and only $25 \%$ of fruits could be classified as first grade fruits (Fig. 4). From the perspective of the producer, the percentage of first grade fruits is even more important than the total yield, because in Estonia the highest price is paid for first grade fruits. Here, fertilization plays an important role. Fertilization had a positive effect on fruit size in both mulches and also as an average for the experiment (Fig. 4). In addition there was a tendency for fertilization to have a greater effect on plastic-mulch-grown plants than on strawmulch-grown ones, which was probably due to the fact that, before fertilization, plants grown with plastic mulch had poorer growing conditions than those grown with straw mulch. At the same time, the highest number of first grade fruits (171g per plant) was obtained using fertilizers together with straw mulch. Several researchers have noted that the nutrient status of plants in the field can strongly influence fruit quality (Kader 1991, Perkins-Veazie and Collins 1995). As Wang and Lin (2002) have noted, using compost as a soil supplement increased fruit size of strawberry cultivars 'Allstar' and 'Honeoye'.

Comparing different mulches, it can be seen that, without fertilizers, straw mulch should be used in order to get more first grade fruits. Compared to plastic mulch, the yield of first grade fruits on straw mulch was more than double (62 and $133 \mathrm{~g}$ per plant, respectively). It is also interesting that the yield of first grade fruits from the unfertilized variant with straw mulch was almost equal to the yield from the fertilized variant with plastic mulch (102 and 96 g per plant,

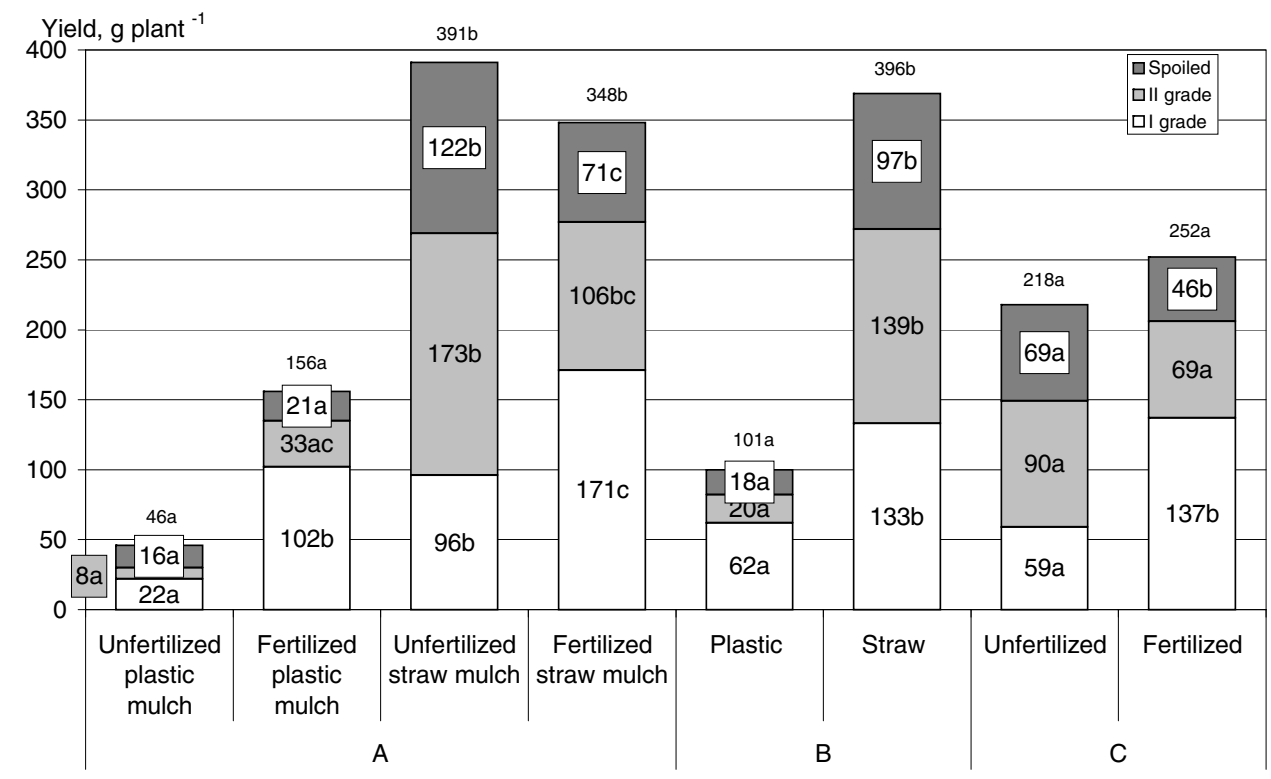

Fig. 4. Influence of fertilization and mulching on total yield and yield quality of strawberry 'Bounty' in a fouryear-old plantation. A - effect of variant; B - average effect of mulch; C - average effect of fertilization. 
Moor, U. et al. Effect of mulching and fertilization on the quality of strawberries

respectively). Such a great positive effect of straw mulch could also have been intensified by the weather conditions in the summer of 2002. Very dry weather prevailed in Estonia during the whole of May until the last ten days of June. Fruit size of strawberries grown on straw mulch was probably greater because the soil under straw mulch had better properties than the soil under the plastic mulch. It is claimed that highest strawberry yields are obtained when plants are grown in deep fertile soil, with high organic matter content and good drainage (Hancock 1999). It is obvious that due to cultivation, the soil under straw is better aerated than that under the plastic cover, where it stays untouched for years. Also, black plastic accumulates more heat than straw, and this could have had an influence on the research results. As found by Wang and Camp (2000), strawberry fruit size was smallest at the highest temperatures $\left(30 / 22^{\circ} \mathrm{C}\right)$ and greatest with cool day and cool night temperatures $\left(18 / 12^{\circ} \mathrm{C}\right)$. Since the average diurnal temperatures reached $15^{\circ} \mathrm{C}$ in June, the daytime temperature for most of the days in June must have been more than $17^{\circ} \mathrm{C}$. Thus it is possible that this could have been an inhibiting factor for fruit growth on plastic mulch.

\section{Vitamin C}

The vitamin in fruits and vegetables most important for human nutrition is vitamin $\mathrm{C}$ (Lee and Kader 2000). Vitamin C inhibits LDL (lowdensity lipoprotein) oxidation through an LDLspecific antioxidant action (Frei 1999). Thus, we may say that vitamin $\mathrm{C}$ is one of the major quality parameters from the consumer's point of view.

In the current experiment, vitamin $\mathrm{C}$ content in strawberry fruits varied between 7.1 and 20.0 mg $100 \mathrm{~g}^{-1}$ fresh weight (FW) (Fig. 5). Usually, average content of vitamin $\mathrm{C}$ in strawberry fruits is around $65.0 \mathrm{mg} 100 \mathrm{~g}^{-1} \mathrm{FW}$ (Agar et al. 1997)

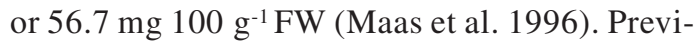
ous studies in Estonia have shown that content of vitamin $\mathrm{C}$ in fruits of 'Senga-Sengana' (one

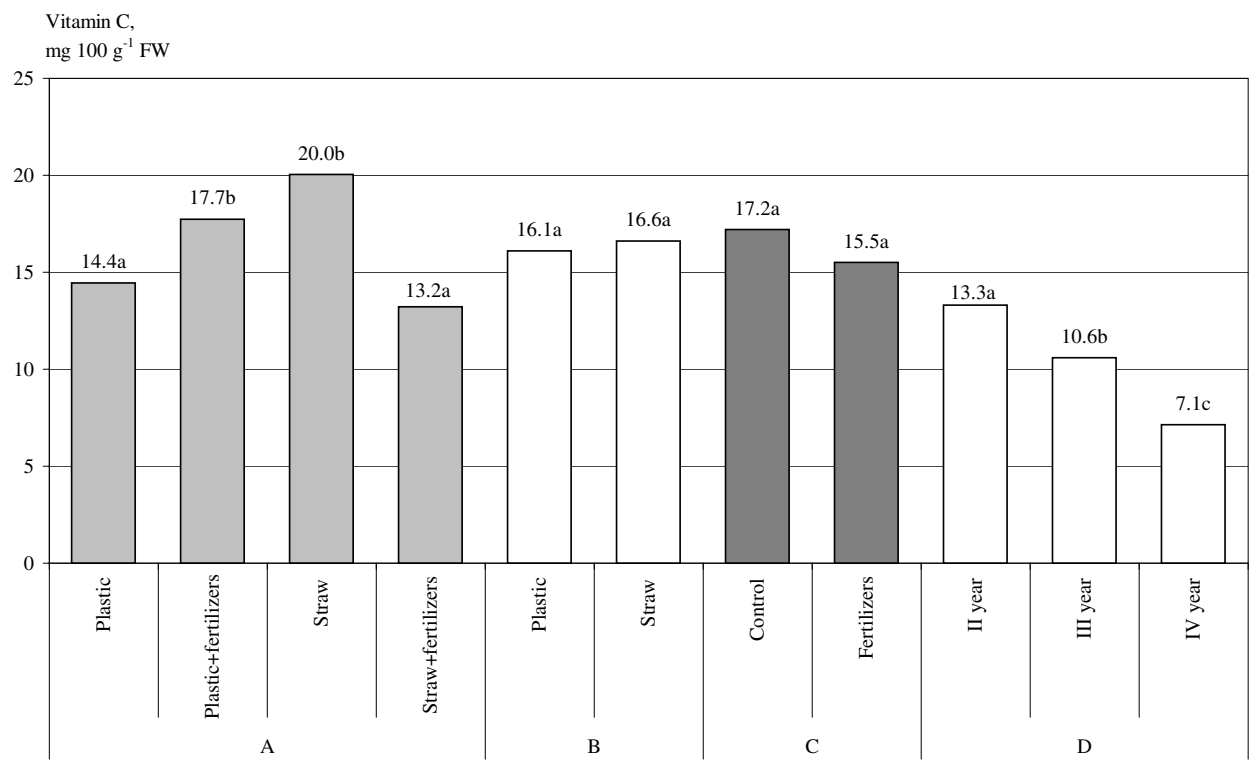

Fig. 5. Influence of fertilization, mulching and plantation age on the vitamin $\mathrm{C}$ content of strawberry 'Bounty' fruits. $\mathrm{A}$ - effect of variant; B - average effect of mulch; C - average effect of fertilization; D - effect of plantation age. 
Vol. 13 (2004): 256-267.

parent of 'Bounty') has been $47 \mathrm{mg} 100 \mathrm{~g}^{-1} \mathrm{FW}$ and in 'Jonsok' (another widely spread strawberry cultivar in Estonia) it has been $39 \mathrm{mg} 100$ $\mathrm{g}^{-1} \mathrm{FW}$ (Libek 1996). Bentvelsen and Bouw (2002) found that content of vitamin $C$ in strawberry fruit varies widely from year to year, ranging from minimum of 6 to maximum of $156 \mathrm{mg}$ $100 \mathrm{~g}^{-1} \mathrm{FW}$. As concluded by Lee and Kader (2000), among preharvest factors, light intensity and temperature are the most important in determining the final vitamin $\mathrm{C}$ content of the commodity. Commodities grown in cool temperatures tend to contain more vitamin $\mathrm{C}$ than those grown in hot temperatures (Klein and Perry 1982, Lee and Kader 2000). In general, the lower the light intensity during growth, the lower the ascorbic acid content of plant tissues. Outside fruit exposed to maximum sunlight contain a higher amount of vitamin $\mathrm{C}$ than inside and shaded fruit on the same plant (Harris 1975). As all the fruits in this experiment were picked from outside the plant canopy, and the irradiation in June was slightly higher than the average for many years, this could not be a limiting factor for the accumulation of vitamin $\mathrm{C}$. The relatively low content of vitamin $C$ could be caused by insufficient water supply during the growth period and high temperatures during fruit ripening.

Fertilization had a significant influence on content of vitamin $\mathrm{C}$ both with plastic and with straw mulch, but the influence was in opposite directions (Fig. 5). With plastic mulch, fertilization had a positive influence, increasing content of vitamin $\mathrm{C}$ in fruits by $3 \%$. In contrast, for straw mulch, fertilization decreased the content of vitamin $\mathrm{C}$ in fruits by as much as $10 \%$. The average effect of mulches on the vitamin $\mathrm{C}$ content was not significant. The contrasting effect of fertilization could be the consequence of large differences in plant growth conditions before fertilization. As the plantation with straw mulch was scarified and defoliated by burning, and the ashes of the straw also acted as a fertilizer, plants with straw mulch had much better growing conditions, and did not have need for much additional fertilization. Plants grown with plastic mulch had worse growing conditions due to poor aeration and probably due to the lack of available nutrients in the soil, and therefore reacted positively to the injected fertilizer solution.

The age of plants had a significant negative influence on content of vitamin C in strawberry fruits. Strawberries from a three-year-old plantation contained $80 \%$ of the vitamin C, and strawberries from a four-year-old plantation only $54 \%$ of the vitamin $\mathrm{C}$ of strawberries from a two-yearold plantation. Another observation can be made by looking at the content of vitamin $\mathrm{C}$ in strawberry fruits from four-year-old plantations with straw mulch, but different fertilizer applications. In the variant where fertilizer solution was injected, the content of vitamin $\mathrm{C}$ in strawberry fruits was $13.2 \mathrm{mg} 100 \mathrm{~g}^{-1} \mathrm{FW}$, but in the variant where granulated fertilizer was used, it was only $7.1 \mathrm{mg} 100 \mathrm{~g}^{-1} \mathrm{FW}$ (Fig. 5). As there was almost no rain in May and in the first two thirds of June, granulated fertilizer was not available for plants and could not influence fruit quality.

Knowing that plant age strongly influences vitamin $\mathrm{C}$ content, we analysed fruits from the three-year-old plantation to see if fruit size also has an impact on the content of vitamin $\mathrm{C}$.

Fruit size and vitamin $\mathrm{C}$ content were negatively correlated (Fig. 6). In the three-year-old plantation, smaller fruits contained more vitamin $\mathrm{C}$ than larger fruits $(\mathrm{r}=0.47, \mathrm{P}<0.05)$.

\section{Soluble solids}

Strawberry flavour is a complex combination of sweetness, acidity and aroma. The most intensely flavoured fruits generally have high levels of both titratable acidity and soluble solids, whereas the bland fruits are low in both these components (Kader 1991). High sugar and lower acidity will be preferred by many consumers (Haffner 2002). Soluble solids content can be considered an important quality attribute from the viewpoint of both consumer and producer.

Content of soluble solids of strawberry fruits in the current experiment varied between 10.4 and $11.5 \%$. Studies by different authors have 
Moor, U. et al. Effect of mulching and fertilization on the quality of strawberries

Fig. 6. Relationship between fruit size (g) and fruit vitamin $\mathrm{C}$ content (mg $\left.100 \mathrm{~g}^{-1} \mathrm{FW}\right)$.

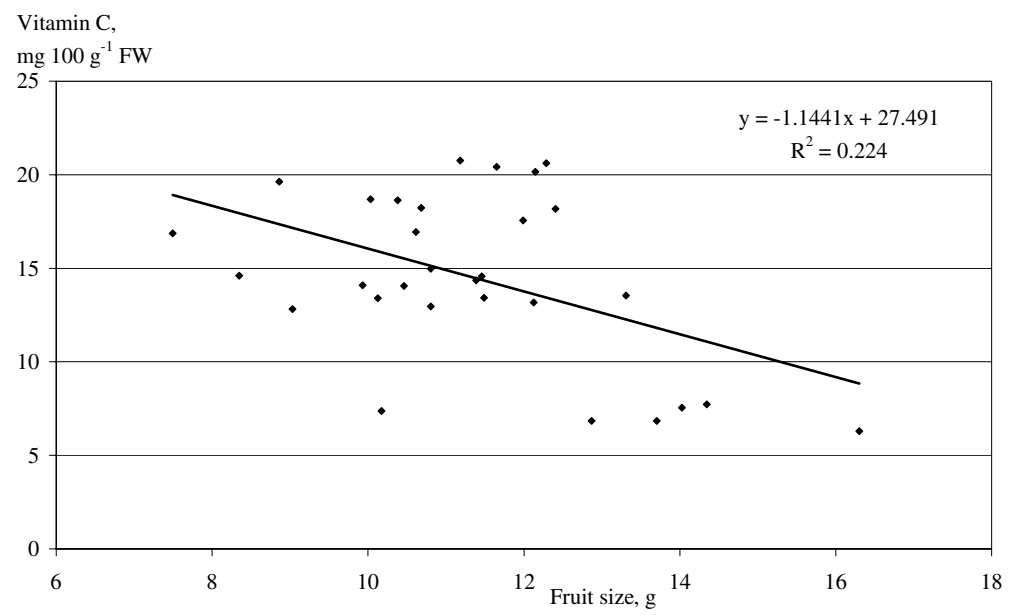

shown that soluble solids content in ripe strawberries is usually between 6 and 9\% (Spayd and Morris 1981, Kader 1991). The cause of the high content of soluble solids in strawberry fruits in the current experiment could be water stress and high light intensity during fruit development and ripening. On the other hand, high soluble solids content can also be characteristic of cultivar Bounty fruits. If the taste of 'Bounty' is compared to several other strawberry cultivars grown in Estonia, 'Bounty' has a sweeter taste. We can conclude that taste and soluble solids are related, based on knowledge that glucose, fructose, and sucrose are the major soluble sugars found in the fruit of strawberries during all stages of ripening (Maas et al. 1996).

In our experiment, none of the experimental factors had a significant effect on the content of soluble solids. There are different opinions about what influences soluble solids content in strawberries. Hancock (1999) has mentioned that like all other fruit quality parameters, soluble solids are dependent on cultivar and environmental conditions. Shaw (1990) showed that soluble solids content was more dependent on environmental conditions than genetic inheritance. On the other hand Duewer and Zych (1967) reported that the soluble solids content of five cultivars grown for 3 years was quite different among cultivars, but varied little from year to year. The results from our experiment indicate that the soluble solids content of strawberry 'Bounty' fruits is not easily influenced by different growing systems, at least not in the weather conditions described. Further research is needed to determine the effect of different weather conditions on soluble solids content of 'Bounty' strawberry fruits.

\section{Fruit cracking}

There was very little precipitation until the last third of June, when $50 \mathrm{~mm}$ of rain fell in nine days. Such a big change in water supply within so short a time caused remarkable damage in strawberry fruits: $55-79 \%$ of the fruits from one harvest were spoiled (Fig. 7). Such extensive damage was probably caused by the very sudden expansion of cells, which caused cracking (Fig. 8).

As the results of our research showed, the average effect of mulching and fertilization on the number of cracked fruits from one picking was insignificant (Fig. 7). Comparing different variants, fertilization had a positive effect on fruits grown on straw mulch by decreasing the number of cracked fruits by $12 \%$. Plantation age 
Vol. 13 (2004): 256-267.
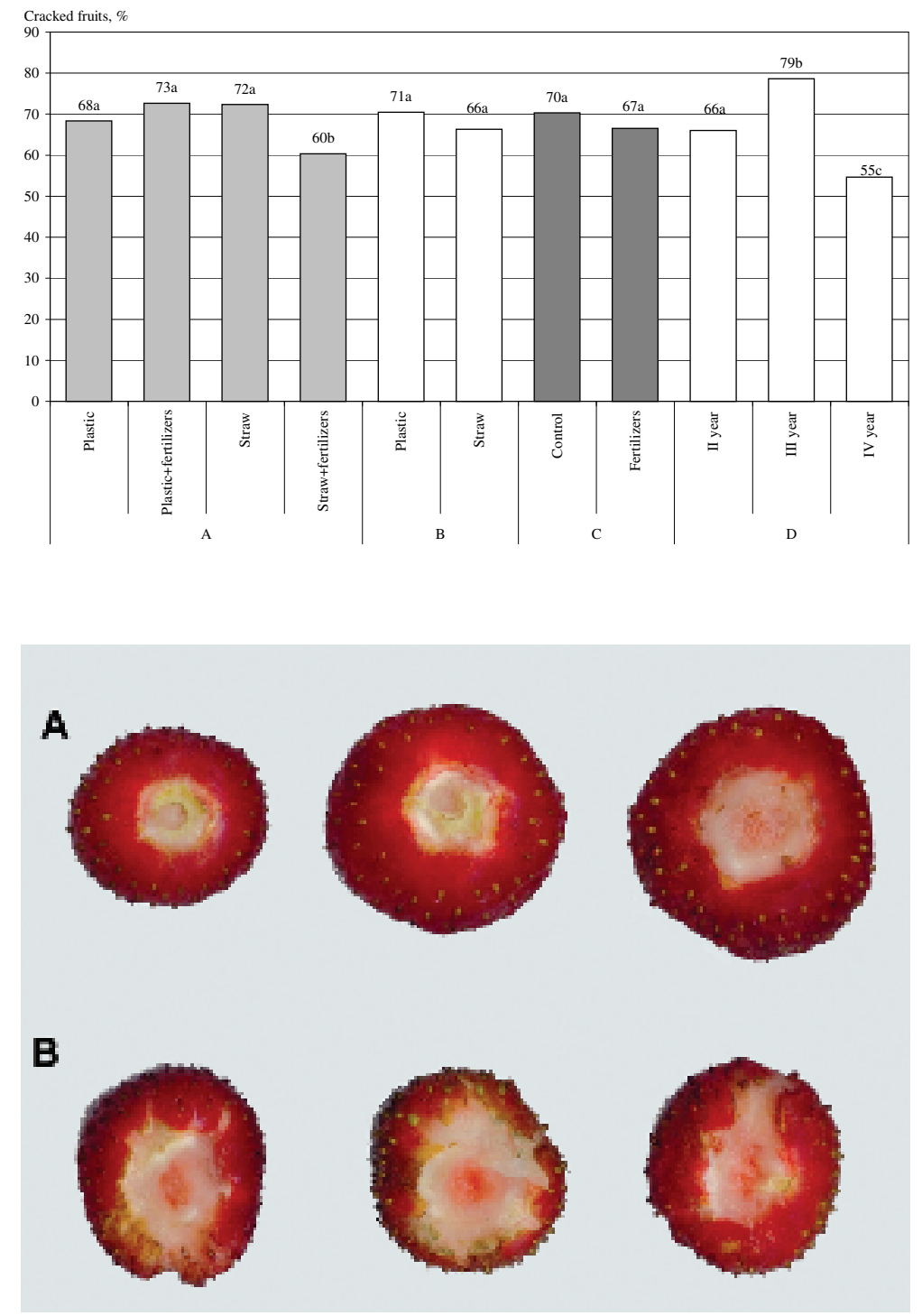

Fig. 7. Influence of fertilization, mulching and plantation age on the number of cracked fruits of strawberry 'Bounty'. A - effect of variant; B - average effect of mulch; $\mathrm{C}$ - average effect of fertilization; $\mathrm{D}$ - effect of plantation age.

Fig. 8. Images of undamaged fruits (A) and cracked fruits (B) of strawberry 'Bounty' as seen from under the calyx. (Photo: Ulvi Moor).

also had a remarkable effect on the number of cracked fruits. The observed differences are difficult to explain, because the number of cracked fruits was $19 \%$ higher in the three-year-old plantation than in the two-year-old plantation, but, at the same time, in the four-year-old plantation the number of cracked fruits decreased by $18 \%$ compared to the two-year-old plantation. Since average fruit size in the four-year-old plantation is smaller compared to younger plantations, this could be the reason for less damage. The reason why fruits of three-year-old plants cracked more than those of two-year-old plants could have something to do with the different content of calcium in plants. As shown by Karp et al. (2002), calcium content in fruits of strawberry 
Moor, U. et al. Effect of mulching and fertilization on the quality of strawberries

'Jonsok' was highest in the third year. We suggest that it might be the same with cultivar Bounty and that this had an impact on fruit firmness and therefore also on cracking. Calcium has long been implicated in fruit firmness and rot resistance, but calcium applications have had variable results, depending on cultivar, rate, and timing (Cheour et al. 1990). The mechanisms through which plantation age influences the susceptibility of strawberry fruits to mechanical damage need further analysis.

From the results of our research we can conclude that injecting fertilizer solution into the soil under plastic mulch is an effective and inexpensive way to avoid a decrease in the number of first grade fruits in the third year of strawberry production. Vitamin $\mathrm{C}$ content was negatively influenced by plant age, and in the three-yearold plantation, smaller fruits contained more vitamin $\mathrm{C}$ than bigger fruits. Mulches did not influence the number of damaged fruits, but with straw mulch, the applied fertilizer solution decreased fruit damage.

Acknowledgements. The authors would like to thank the companies Vasula Aed and Kemira GrowHow for their financial support and Estonian Meteorological and Hydrological Institute for weather data. Also technical assistance of T. Tõnutare is appreciated.

\section{References}

Agar, I.T., Streif, J. \& Bangerth, F. 1997. Effect of high $\mathrm{CO}_{2}$ and controlled atmosphere on the ascorbic and dehydroascorbic acid content of some berry fruits. Postharvest Biology and Technology 11: 47-55.

Bentvelsen, G.C.M. \& Bouw, E. 2002. Breeding Strawberry $\mathrm{F} 1$-Hybrids for vitamin $\mathrm{C}$ and sugar content. Acta Horticulturae 567: 813-814.

Ceponis, M.J., Capellini, R.A. \& Lightner, G.W. 1987. Disorders in sweet cherry and strawberry shipments to the New York market, 1972-1984. Plant Disease 71: 472-475.

Cheour, F., Willemot, C., Arul, J., Makhlouf, J., Charest, P.M. \& Gosselin, A. 1990. Foliar application of Calcium chloride delays postharvest ripening of strawberry. Journal of the American Society for Horticultural Science 115: 789-792.
Duewer, R.G. \& Zych, C.C. 1967. Heritability of soluble solids and acids in progenies of the cultivated strawberry (Fragaria $x$ ananassa Duch.). Proceedings of the American Society for Horticultural Science 90: 153-157.

Frei, B. 1999. On the role of Vitamin C and other antioxidants in atherogenesis and vascular dysfunction. Proceedings of the Society for Experimental Biology and Medicine. Volume 222, Issue 3, p. 196.

Haffner, K. 2002. Postharvest quality and processing of strawberries. Acta Horticulturae 567: 715-722.

Hancock, J.F. 1999. Strawberries. Crop production science in horticulture 11. CABI Publishing. $237 \mathrm{p}$.

Harris, R.S. 1975. Effects of agricultural practices on the composition of foods. In: Harris, R.S. \& Karmas, E. (eds.). Nutritional evaluation of food processing. 2nd ed. AVI, Westport, CT. p. 33-57.

Kader, A.A. 1991. Quality and its maintenance in relation to the postharvest physiology of strawberry. In: Luby J.J. \& Dale, A. (eds.). The Strawberry into the 21 st century. Timber Press, Portland, Oregon. p. 145-152.

Karp, K. \& Starast, M. 2002. Effects of springtime foliar fertilization on strawberry yield in Estonia. Acta Horticulturae 594: 501-505.

Karp, K., Starast, M. \& Kaldmäe, H. 2002. Influence of the age of plants and foliar fertilization on the yield of strawberry cultivar Jonsok under plastic mulch. Acta Horticulturae 567: 459-462.

Klein, B.P. \& Perry, A.K. 1982. Ascorbic acid and vitamin A activity in selected vegetables from different geographical areas of the United States. Journal of Food Science 47: 941-945.

Lee, S.K. \& Kader, A.A. 2000. Preharvest and postharvest factors influencing vitamin $C$ content of horticultural crops. Postharvest Biology and Technology 20: 207-220.

Libek, A. 1996. Sordid (Cultivars). In: Eskla, V. (ed.). Maasikakasvatus (Strawberry growing). p. 7-18. (in Estonian).

Lille, T., Karp, K. \& Värnik, R. 2003. Profitability of different technologies of strawberry cultivation. Agronomy research 1: 75-83.

Maas, J.L., Wang, S.Y. \& Galletta, G.J. 1996. Health enhancing properties of strawberry fruit. In: Pritts, M.P. et al. (eds.). Proceedings of the IV North American Strawberry Conference. Orlando, Florida. p. 11-18.

Nwankwo, S. 1995. Developing a customer orientation. The Journal of Customer Marketing 12: 5-15.

Perkins-Veazie, P. \& Collins, J.K. 1995. Strawberry fruit quality and its maintenance in postharvest environments. Advances in Strawberry Research 14: 1-8.

Prussia, S.E. \& Shewfelt, R.L. 1993. Systems approach to postharvest handling. In: Shewfelt, R.L. \& Prussia, S.E. (eds.). Postharvest handling: a systems approach. Academic Press, San Diego. p. 43-71.

Shaw, D. 1990. Response to selection and associated changes in genetic variance for soluble solids and titratable acids content in strawberries. Journal of the American Society for Horticultural Science 115: 839843.

Shewfelt, R.L. 1999. What is quality? Postharvest Biology and Technology 15: 197-200. 


\section{AGRICULTURAL AND FOOD SCIENCE}

Vol. 13 (2004): 256-267.

Spayd, S.E. \& Morris, R.S. 1981. Physical and chemical characteristics of puree from once-over harvested strawberries. Journal of the American Society for Horticultural Science 106: 101-105.

Van Trijp, H.C.M. \& Schifferstein, H.N.J. 1995. Sensory analysis in marketing practice: comparison and integration. Journal of Sensory Studies 10: 127-147.
Wang, S.Y. \& Camp, M.J. 2000. Temperatures after bloom affect plant growth and fruit quality of strawberry. Scientia Horticulturae 85: 183-199.

Wang, S.Y. \& Lin, S.-S. 2002. Composts as soil supplement enhanced plant growth and fruit quality of strawberry. Journal of Plant Nutrition 25: 2243-2259. 